\title{
Sequelae of Neonatal Jaundice
}

\author{
PHYLLIS CULLEY,* M.B., CH.B. ; JEAN POWELL, $\dagger$ B.SC. ; JOHN WATERHOUSE, $\ddagger$ M.A., PH.D. \\ BEN WOOD, $\oint$ D.M., F.R.C.P., D.C.H.
}

\begin{abstract}
Cummary: A total of 371 newborn infants falling into 3 $\checkmark$ groups, non-haemolytic jaundice, haemolytic jaundice, and non-jaundiced controls, have been reassessed in the 6th year of life as regards neurological, audiological, and psychological function. Neurological handicap was concentrated among the infants of low birth weight and was not related to jaundice, apart from one case of athetoid cerebral palsy with deafness. No other cases of perceptive deafness were discovered. Intelligence testing on the Stanford Binet scale showed no relation between depth of jaundice and I.Q.

These findings support the majority of reports in the literature that reduction in intelligence does not occur in non-haemolytic jaundiced babies with serum bilirubin below about $20 \mathrm{mg} . / 100 \mathrm{ml}$. In haemolytic jaundice slight doubt remains. There is no indication for changing present standards for exchange transfusion.
\end{abstract}

\section{Introduction}

The end results of severe jaundice in rhesus haemolytic disease were clearly established as athetoid cerebral palsy, high tone deafness, and staining of the teeth (Gerrard, 1952). A definite decrease of such handicaps followed the introduction of exchange transfusion, but the effect on later intelligence was questioned by Day and Haines (1954), who showed a slight reduction of I.Q. in the otherwise intact jaundiced infant compared with its non-jaundiced sibling. Other workers have reported equivocally since then, and this is discussed later.

Aside from haemolytic disease neonatal jaundice of any severity is mainly associated with low birth weight. In many of these infants the jaundice may be an associated finding, with other factors, such as hypoxia, acidaemia, or hypoglycaemia, contributing to the high incidence of neurological deficit which has been shown on later assessment by such observers as Drillien (1964) and McDonald (1967). This is discussed later.

The serum bilirubin level above which damage is likely to occur depends on factors such as those mentioned above, but the original level of $20 \mathrm{mg} . / 100 \mathrm{ml}$. as stated by Mollison and Cutbush (1954) was generally accepted until Boggs et al. (1967) showed a reduction in developmental status measured at the age of 8 months in babies with levels of $16 \mathrm{mg} . / 100 \mathrm{ml}$. or even lower. This was interpreted by Waltman et al. (1969) that "S.B. [serum bilirubin] levels in the newborn above $7.5 \mathrm{mg} . / 100$ ml. may be associated with low mental and/or motor scores at 8 months of age." This, if accepted, would alter the indications for exchange transfusion or other treatment out of all recognition from the present standards.

\section{Present Study}

This concerns the assessment up to the sixth year of three groups of infants born at the Birmingham Maternity Hospital between 1958 and 1960. One group had non-haemolytic jaundice and were compared with non-jaundiced controls. The

\footnotetext{
* Medical Assistant in Paediatrics, Birmingham Maternity Hospital. + Statistical Officer, Department of Social Medicine, University of
Birmingham.

₹ Reader in Medical Statistics, University of Birmingham.

\& Consultant Paediatrician, United Birmingham Hospitals.
}

third group had jaundice due to rhesus haemolytic disease Very high levels of serum bilirubin were not encountered, because therapy aimed at maintaining the level below $20 \mathrm{mg} . / 100 \mathrm{ml}$. if possible.

\section{Non-haemolytic Jaundice}

The original sample has already been described by Wood et al. (1962) and is shown in Table I. The jaundice was first assessed by Gossett icterometer, every tenth non-jaundiced child being selected as a control. If the icterometer reading remained at 3 or below the jaundice was described as mild; over this reading serum bilirubin levels were estimated and up to $16 \mathrm{mg} . / 100 \mathrm{ml}$. was described as moderate and above that as severe.

When these infants were 1 year old two of us (P.C. and B.W.) carried out an abbreviated Griffiths (1954) type developmental test, using a total of 20 items. The results suggested that jaundice was having an effect on progress even at moderate levels (serum bilirubin 12-16 mg./100 ml.). No allowance was made for gestation, with the result that the more premature infants were being seen at a "gestational age" of well under 1 year. It was therefore decided to follow as many of these children as possible up to the age of school entry in the sixth year of life.

The numbers seen again at this time are also shown in Table I. This sixth-year assessment was carried out by the same two paediatricians, by an audiologist, and by a team of psychologists and psychiatric social workers led by $\mathrm{Mr}$. C. J. Phillips, of the Centre for Child Study, University of Birmingham, supported by a grant from the Mental Health Research Fund. The tests devised for each child and the interview with the mother took half a day, so the numbers had to be restricted. Mildly jaundiced infants over $2.5 \mathrm{~kg}$. were excluded and a sample (46) only of mildly jaundiced infants under that weight were examined. Forty-eight nonjaundiced babies over $2.5 \mathrm{~kg}$. at birth were tested as controls after random selection among the babies born over this period. With these exceptions every effort was made to trace and examine the remainder, so that it is not felt that the fallout of cases was sufficient to affect the results.

\section{Haemolytic Jaundice}

Early in the study it became apparent that it was going to be difficult to distinguish between the effects of jaundice itself on later development and the effects of low birth weight or prematurity, which usually accompanies jaundice of nonhaemolytic origin. It was therefore decided to add to the follow-up study all infants born at the same time who had suffered from rhesus haemolytic disease with moderate to severe degrees of jaundice: 45 such infants were born over this period and 43 were subjected to the full assessment.

\section{Results}

\section{Non-haemolytic Jaundice}

Table II shows the follow-up arranged as in Table I, giving the numbers of handicapped children who would probably need special consideration for schooling on account of neurological deficit or mental retardation. 
TABLE I.-Original Group and Sixth-year Assessment

\begin{tabular}{|c|c|c|c|c|c|c|c|c|c|c|c|c|c|c|c|}
\hline & & & & & & & & \multicolumn{4}{|c|}{ Birth Weight $2.5 \mathrm{~kg}$. and Under } & \multicolumn{4}{|c|}{ Birth Weight Over $2.5 \mathrm{~kg}$} \\
\hline & & & & & & & & \multicolumn{4}{|c|}{ Degree of Jaundice } & \multicolumn{4}{|c|}{ Degree of Jaundice } \\
\hline & & & & & & & & Nil & Mild & $\begin{array}{c}\text { Moderate } \\
12-16 \\
\text { S.B. mg. }\end{array}$ & $\begin{array}{c}\text { Severe } \\
>16 \\
>100 \mathrm{ml} .\end{array}$ & Nil & Mild & $\begin{array}{c}\text { Moderate } \\
12-16 \\
\text { S.B. mg./ }\end{array}$ & $\begin{array}{c}\text { Severe } \\
>16 \\
100 \mathrm{ml} .\end{array}$ \\
\hline Original group at birth & . & $\ldots$ & . & $\ldots$ & .. & $\ldots$ & .. & 131 & 149 & 40 & 17 & 209 (S.O.) & 435 & 55 & 26 \\
\hline 6th-year group .. & . & .. & . & . & .. & . & .. & 111 & 46 (S.O.) & 34 & 16 & 48 (S.O.) & 0 & 49 & 24 \\
\hline \multicolumn{3}{|c|}{ Percentage follow-up of original group } & . & . & .. & . & . & 84 & - & 85 & 94 & - & - & 88 & 93 \\
\hline
\end{tabular}

S.B. $=$ Serum bilirubin. S.O. $=$ Sample only.

TABLE II.-Overall Results of Assessment in Sixth Year

\begin{tabular}{|c|c|c|c|c|c|c|c|c|c|c|c|c|c|c|c|c|}
\hline & & & & & & & & & \multicolumn{4}{|c|}{ Birth Weight $2.5 \mathrm{~kg}$. and Under } & \multicolumn{4}{|c|}{ Birth Weight over $2.5 \mathrm{~kg}$. } \\
\hline & & & & & & & & & \multicolumn{4}{|c|}{ Degree of Jaundice } & \multicolumn{4}{|c|}{ Degree of Jaundice } \\
\hline & & & & & & & & & Nil & Mild & $\begin{array}{c}\text { Moderate } \\
12-16 \\
\text { S.B. mg. }\end{array}$ & $\begin{array}{c}\text { Severe } \\
16+ \\
100 \mathrm{ml} .\end{array}$ & Nil & Mild & $\begin{array}{c}\text { Moderate } \\
12-16 \\
\text { S.B. mg./ }\end{array}$ & $\begin{array}{c}\text { Severe } \\
16+ \\
00 \mathrm{ml} .\end{array}$ \\
\hline 6th-year group $\ldots$ & . & . & . & .. & . & . & .. & $\ldots$ & 111 & 46 & 34 & 16 & 48 & 0 & 49 & 24 \\
\hline C.N.S. deficit ( $\%)$ & . & . & . & .. & .. & $\ldots$ & .. & .. & $9(8)$ & $2(4)$ & 0 & $2(13)$ & $\mathbf{0}$ & 0 & $1(2)$ & $1(4)$ \\
\hline Mental handicap (I.Q. & $<80)$ & $\%)$ & .. & .. & .. & .. & . & .. & $15(13)$ & $11(24)$ & $2(6)$ & $1(6)$ & $\mathbf{0}$ & 0 & $1(2)$ & $\mathbf{0}$ \\
\hline Overall handicap (\%) & .. & .. & .. & .. & .. & .. & . & .. & $19(17)$ & $11(24)$ & $2(6)$ & $2(13)$ & - & - & $2(4)$ & $1(4)$ \\
\hline
\end{tabular}

TABLE III.-C.N.S. Deficit in Infants of $2.5 \mathrm{~kg}$. Birth Weight and Under (207 Examined)

\begin{tabular}{|c|c|c|c|c|c|c|c|c|c|c|c|}
\hline \multicolumn{6}{|c|}{ Degree of Jaundice (No. of Cases Examined) } & \multirow{2}{*}{$\begin{array}{c}\begin{array}{c}\text { Birth } \\
\text { Weight } \\
\text { (kg.) }\end{array} \\
1 \cdot 8 \\
2.1 \\
2.3 \\
2.1 \\
2.3 \\
2.3 \\
2.2 \\
2.0 \\
1.9\end{array}$} & \multirow{2}{*}{$\begin{array}{c}\begin{array}{c}\text { Gestation } \\
\text { (Weeks) }\end{array} \\
40 \\
37 \\
34 \\
37 \\
40 \\
40 \\
41 \\
42 \\
40\end{array}$} & \multirow{2}{*}{$\begin{array}{c}\begin{array}{c}\text { I.U. } \\
\text { Percentile }\end{array} \\
<10 \\
10 \\
75 \\
10 \\
<10 \\
<10 \\
<10 \\
<10 \\
<10\end{array}$} & \multirow{2}{*}{$\begin{array}{l}\qquad \text { Perinatal Factors } \\
\text { P.E.T. Fetal distress } \\
\text { 1st twin. (Twin 2 macerated) } \\
\text { P.E.T. } \\
\text { Placental infarction } \\
\text { Maternal thyrotoxicosis } \\
\text { P.E.T. }\end{array}$} & \multirow{2}{*}{$\begin{array}{l}\text { Type of Deficit } \\
\text { Hemiplegia } \\
\text { ”, } \\
\text { Microcephaly } \\
\text { "” } \\
\text { Mixed" athetoid } \\
\text { Ataxic }\end{array}$} & \multirow{2}{*}{\begin{tabular}{r|}
.$Q$. \\
80 \\
107 \\
69 \\
102 \\
43 \\
33 \\
69 \\
39 \\
93
\end{tabular}} \\
\hline Non-jaundiced (111 exam & ned) & $\ldots$ & . & . & $\ldots$ & & & & & & \\
\hline Mild (46 examined) .. & . & . & . & . & $\cdots$ & $\begin{array}{l}2 \cdot 5 \\
2 \cdot 2\end{array}$ & $\begin{array}{l}38 \\
36\end{array}$ & $\begin{array}{r}<25 \\
25\end{array}$ & Breech. Twin 2 & $\begin{array}{l}\text { Hemiplegia } \\
\text { Ataxic }\end{array}$ & $\begin{array}{l}52 \\
76\end{array}$ \\
\hline Moderate ( 34 examined) & . & . & . & . & . & - & - & - & - & 0 & - \\
\hline Severe (16 examined) & .. & $\cdots$ & . & . & . & $\begin{array}{l}1.9 \\
1.9\end{array}$ & $\begin{array}{l}33 \\
34\end{array}$ & $\begin{array}{l}50 \\
50\end{array}$ & $\begin{array}{l}\text { R.D.S. Birth asphyxia. Max. } \\
\text { bilirubin } 16.0 \mathrm{mg} . / 100 \mathrm{ml} \text {. } \\
\text { Locked twin, breech extraction. } \\
\text { Max. bilirubin } 16.1 \mathrm{mg} . / 100 \mathrm{ml} \text {. }\end{array}$ & $\begin{array}{l}\text { Diplegia } \\
\text { Microcephaly } \\
\text { Mixed C.P. }\end{array}$ & $\begin{array}{r}102 \\
<50\end{array}$ \\
\hline
\end{tabular}

P.E.T. $=$ Pre-eclamptic toxaemia. R.D.S. $=$ Respiratory distress syndrome.

Neurological deficit.-Only two babies over $2.5 \mathrm{~kg}$. birth weight were handicapped at 5 years. The first was moderately jaundiced and had minimal clumsiness with an I.Q. of 85. The second was of 36 weeks' gestation and more severely jaundiced. The neurological lesion of spastic diplegia is typical of prematurity rather than of hyperbilirubinaemia, and the child's I.Q. was 93. In the low birth weight group (Table III) 9 of the 13 with neurological handicap never showed clinical jaundice, all but one being under the 10th percentile on the Lubchenko intrauterine growth chart. The two mildly jaundiced babies were small for dates, one had a hemiparesis following breech twin delivery and the other was ataxic. In the severely jaundiced group one infant showed the usual picture of spastic diplegia after premature delivery at 33 weeks with a maximum bilirubin level of $16 \mathrm{mg} . / 100 \mathrm{ml}$, the I.Q. at five years being 102. The other infant of similar birth weight and gestation was a first twin who presented great difficulties in delivery. The twins were locked, and this baby was delivered by breech. There was difficulty in resuscitation and the infant showed delay in all motor milestones thenceforward. The maximum bilirubin in the neonatal period was $16.1 \mathrm{mg} . / 100 \mathrm{ml}$., and at five years the child showed spastic quadriparesis with some athetoid features, microcephaly, and an I.Q. which was not testable. The causes of this damage are thought to be due to the delivery rather than the jaundice.
Hearing.-Of the 230 children examined, 220 were normal and 10 abnormal; 91 were not examined. None of the abnormal cases had an isolated high tone loss, their defect being ascribed to catarrhal conditions. The results were therefore not pursued further.

Psychological assessment.-The results reported here are confined to the intelligence quotient measured on the Stanford Binet intelligence scale, third revision, form L-M, by Mr. C. J. Phillips and his co-workers. Other investigations, including a number of behavioural tests, are being reported elsewhere. We have shown in previous papers that the degree of jaundice and the proportion of infants affected show wide variations with maturity whether measured by gestation or by weight. It is therefore essential when examining the effects of jaundice to allow for the different distribution by weight or gestation of the babies within each jaundiced group. For this reason our figures of expectations have been standardized for either weight or gestation within each subgroup. The I.Q.s by birth weight, together with expectations computed in this way are given in Table IV. There is clearly no difference between the I.Q.s observed and those expected. When the results were grouped according to gestation a similar lack of correlation was also seen and neither approached significance. As mentioned earlier the developmental tests at one year on a random sample of the original group had shown a reduction in score with increasing levels of jaundice. We therefore cal- 
culated the mean I.Q. of the same infants in the sixth year and compared this with their scores at one year (see Table V). The apparently harmful effect of jaundice shown at 12 months has completely disappeared by the sixth year.

The conclusion is that in non-haemolytic jaundice there is no evidence of reduction in intelligence quotients with increasing jaundice up to the permitted level of around $20 \mathrm{mg} . / 100 \mathrm{ml}$.

TABLE IV.-Mean I. Q. by Birth Weight and Degree of Faundice

\begin{tabular}{|c|c|c|c|c|c|}
\hline Weight (kg.) & Nil & Mild & Moderate & Severe & Total \\
\hline $\begin{array}{l}-1 \cdot 5 \\
-2 \\
-2 \cdot 5 \\
-3 \\
>3\end{array}$ & $\begin{array}{c}105 \cdot 0(2) \\
90.0(19) \\
99 \cdot 1(90) \\
107.5(14) \\
110.5(34)\end{array}$ & $\begin{array}{c}84.7(4) \\
91.4(13) \\
103.5(29) \\
=\end{array}$ & $\begin{array}{r}82.5(2) \\
95 \cdot 2(13) \\
103 \cdot 3(19) \\
106.7(18) \\
105.6(31)\end{array}$ & $\begin{array}{l}102 \cdot \overline{7}(12) \\
105 \cdot 5(4) \\
111 \cdot 4(8) \\
104 \cdot 4(16)\end{array}$ & $\begin{aligned} & 89 \cdot 2(8) \\
& 94 \cdot 2(57) \\
& 100 \cdot 8(142) \\
& 107.9(40) \\
& 107 \cdot 4(81)\end{aligned}$ \\
\hline $\begin{array}{l}\text { Total: } \\
\text { Observed } \\
\text { I.Q. } \\
\text { Expected } \\
\text { I.Q. . . }\end{array}$ & $\begin{array}{l}101 \cdot 3(159) \\
101 \cdot 3(159)\end{array}$ & $\begin{array}{l}98 \cdot 4(46) \\
97 \cdot 0(46)\end{array}$ & $\begin{array}{l}103 \cdot 1(83) \\
103.9(83)\end{array}$ & $\begin{array}{l}105 \cdot 4(40) \\
102 \cdot 6(40)\end{array}$ & $\begin{array}{c}101 \cdot 9(328) \\
-\end{array}$ \\
\hline
\end{tabular}

Figures in parentheses show the number of infants in each group.

T'ABLE V.-Mean D.Q. at One Year Compared with Mean I.Q. at Sixth Year (On Same Group of Infants)

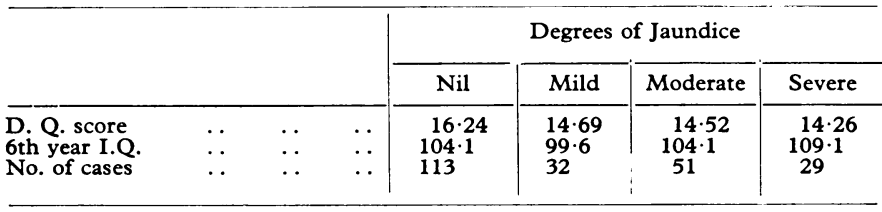

TABLE VI.-Mean I. Q. by Birth Weight and Degree of Haemolytic Faundice

\begin{tabular}{|c|c|c|c|c|c|c|c|}
\hline \multicolumn{6}{|c|}{ Weight (kg.) } & \multirow{2}{*}{$\begin{array}{c}\text { Moderate Jaundice } \\
\overline{-} \\
92 \cdot 5(2) \\
109 \cdot 5(4) \\
106 \cdot 8(5)\end{array}$} & \multirow{2}{*}{$\begin{array}{c}\text { Severe Jaundice } \\
\overline{96 \cdot 0(1)} \\
102 \cdot 2(5) \\
103 \cdot 8(10) \\
104 \cdot 6(16)\end{array}$} \\
\hline $\begin{array}{l}-1.5 \\
-2 \\
-2.5 \\
-3 \\
>3\end{array}$ & $\begin{array}{l}\ldots \\
\cdots \\
\cdots\end{array}$ & $\begin{array}{l}\ldots \\
\cdots \\
\cdots \\
\cdots\end{array}$ & $\begin{array}{l}\ldots \\
\cdots \\
\cdots \\
\cdots\end{array}$ & $\begin{array}{l}\ldots \\
\ldots \\
\ldots \\
\ldots\end{array}$ & $\begin{array}{l}. \\
\therefore \\
\therefore \\
.\end{array}$ & & \\
\hline \multicolumn{2}{|c|}{$\begin{array}{l}\text { Total: } \\
\text { Observed I.Q. } \\
\text { Expected I.Q. }\end{array}$} & 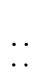 & $\therefore$ & - & . & $\begin{array}{l}105 \cdot 2(11) \\
107 \cdot 3(11)\end{array}$ & $\begin{array}{l}103 \cdot 7(32) \\
107 \cdot 1(32)\end{array}$ \\
\hline
\end{tabular}

Figures in parentheses show the number of infants in each group.

\section{Haemolytic Jaundice}

These 43 infants were assessed in the same way.

Neurological deficit.-All but one were considered normal, the exception having severe athetoid cerebral palsy. It had been impossible to keep the serum bilirubin levels of this infant below $20 \mathrm{mg} . / 100 \mathrm{ml}$., despite three exchange transfusions at 6,22 , and 44 hours of age.

Hearing. - The child mentioned above also had severe high tone hearing loss and was the only one with perceptive deafness of any degree. Three others had conduction loss and five were not tested.

Psychological assessment.-The results of the intelligence tests are shown in Table VI, the expected I.Q. being calculated from the non-jaundiced infants as in Table IV. The observed I.Q. does not differ significantly from the expected.

\section{Very Severe Jaundice}

There were 11 infants whose bilirubin levels rose above 20 mg./100 ml. serum, 5 being non-haemolytic and 6 haemolytic. One was not traced and another was the severe athetoid with hearing loss and an I.Q. of 56. Including him in the mean I.Q. of the 10 tested the result was 99.9 ; if he is excluded as a known neurologically damaged child the mean I.Q. becomes 104.

\section{Discussion}

Taking the two groups together the neurological findings show that by attempting to keep the serum bilirubin level below $20 \mathrm{mg}$. $/ 100 \mathrm{ml}$. only one child develoyed athetoid palsy. The bulk of the handicap was found in the non-haemolytic group among the small-for-dates babies. This merely confirms the work of Drillien (1964) and of McDonald (1967) and shifts the blame for severe brain damage from bilirubin toxicity to the effects of low birth weight itself.

The psycholegical assessment shows that jaundice of either variety up to $20 \mathrm{mg} . / 100 \mathrm{ml}$. has no effect on later intelligence. The literature varies on this point and needs some clarification. Some investigators report haemolytic, others non-haemolytic, and yet others both types of jaundice. The tests themselves have varied from global developmental assessments to established intelligence tests as reported here. A summary of recent reports with these points in view is given in Table VII.

Firstly, there is agreement that non-haemolytic jaundice has no effect on I.Q., at any rate up to levels of $20 \mathrm{mg}$. $/ 100 \mathrm{ml}$., above which level Ose et al. (1967) found development (not intelligence) reduced. Our misleading findings of reduced developmental scores (D.Q.) in the non-haemolytic jaundiced group at one year may well be explained by failure to correct for prematurity.

With haemolytic jaundice Day and Haines (1954) and Van Camp (1964) showed a reduction of I.Q. in the severely jaundiced group but did not report on bilirubin levels. Preisler (1963) took $20 \mathrm{mg} . / 100 \mathrm{ml}$. as the critical level, but the duration of follow-up and the type of test were not clear. On the other hand, Johnston et al. (1967), Holmes et al. (1968), Stewart et al. (1970), Odell et al. (1970), and ourselves report

TABLE VII.-Later Development of Jaundiced Infants. Summary of Reports

\begin{tabular}{|c|c|c|c|c|c|c|c|c|c|c|c|c|}
\hline \multirow{2}{*}{\multicolumn{7}{|c|}{ Author(s) }} & \multicolumn{2}{|c|}{ Numbers } & \multirow{2}{*}{$\begin{array}{l}\text { Type } \\
\text { of } \\
\text { Jaundice }\end{array}$} & \multirow{2}{*}{$\begin{array}{c}\text { S.B. } \\
\text { Levels } \\
\text { (mg.l } \\
100 \mathrm{ml} .)\end{array}$} & \multirow{2}{*}{$\begin{array}{c}\text { Age } \\
\text { (years) } \\
\text { at } F / U .\end{array}$} & \multirow{2}{*}{ Results } \\
\hline & & & & & & & Jaun diced & Controls & & & & \\
\hline Day Haines (1954) & .. & .. & .. & .. & .. & $\bar{\ldots}$ & 68 & 68 & Haem. & - & $2-5$ & Mean I.Q. of J. $=106$. Mean I.Q. of non-J. sib. \\
\hline $\begin{array}{l}\text { Bjure et al. (1961) } \\
\text { Preisler et al. (1963) }\end{array}$ & . & .. & $\therefore$ & :. & $\because$ & .. & $\begin{array}{l}113 \\
109\end{array}$ & 51 & $\begin{array}{l}\text { Non-haem. } \\
\text { Haem. }\end{array}$ & $\begin{array}{r}18-37 \\
+20\end{array}$ & $\stackrel{2-3}{?}$ & $\begin{array}{l}\text { I.Q. of } \mathrm{J}=\text { = I.Q. non-J. } \\
11 \% \text { with S.B. over } 20 \mathrm{mg} . / 100 \mathrm{ml} \text {. retarded }\end{array}$ \\
\hline $\begin{array}{l}\text { Van Camp (1964) } \\
\text { Vuchovich et al. (1965) } \\
\text { Johnston et al. (1967) }\end{array}$ & & $\because$ & $\because$ & $\begin{array}{l}\because \\
\therefore\end{array}$ & $\begin{array}{l}\cdots \\
\cdots\end{array}$ & $\begin{array}{l}\cdots \\
\cdots\end{array}$ & $\begin{array}{r}41 \\
61 \\
129\end{array}$ & $\frac{49}{82}$ & $\begin{array}{l}\text { Haem. } \\
\text { Non-haem. } \\
\text { Haem. }\end{array}$ & $\begin{array}{c} \pm \\
10-37 \\
\pm 18 \\
\text { Over } 20\end{array}$ & $\begin{array}{c}3-15 \\
4 \\
5-6\end{array}$ & $\begin{array}{l}\text { I.Q. of J. somewhat lest than I.Q. of non-J. } \\
\text { I.Q. unrelated to degree of } \mathrm{J} \text {. } \\
\text { Mean I.Q. of } \mathrm{J}=104 \text {. Mean I.Q. of non-J. }\end{array}$ \\
\hline Ose et al. (1967) & & & .. & .. & . & . & $\{109$ & - & Haem. & Up to 35 & $?$ & $\begin{array}{c}=102 \\
\text { Development reduced at S.B. levels above }\end{array}$ \\
\hline $\begin{array}{l}\text { Holmes et al. (1968) } \\
\text { Stewart et al. (1970) } \\
\text { Odell et al. }(1970) \\
\text { Present series }\end{array}$ & $\begin{array}{l}\cdots \\
\because \\
\cdots\end{array}$ & $\begin{array}{l}\cdots \\
\cdots \\
\cdots\end{array}$ & $\begin{array}{l}\cdots \\
\cdots \\
\cdots\end{array}$ & $\begin{array}{l}\because \\
\therefore \\
\therefore\end{array}$ & $\begin{array}{l}\because \\
\because \\
\because\end{array}$ & $\because$ & $\begin{array}{r}48 \\
63 \\
126 \\
32 \\
179 \\
43\end{array}$ & $\frac{17}{159}$ & $\begin{array}{c}\text { Non-haem. } \\
\text { Both } \\
\text { Haem. } \\
\text { Both } \\
\text { Non-haem. } \\
\text { Haem. }\end{array}$ & $\frac{5-23}{13 \cdot 6-31 \cdot 2}$ & $\begin{array}{l}4-8 \\
7-14 \\
4-7 \\
5 \frac{1}{2}\end{array}$ & $\begin{array}{l}\text { Motor development unrelated to degree of J. } \\
\text { I.Q. unrelated to degree of J. } \\
\text { I.Q. unrelated to S.B. levels } \\
\text { I.Q. unrelated to degree of J. }\end{array}$ \\
\hline
\end{tabular}


no effect of bilirubin levels on later I.Q. Stewart and his colleagues make the point that subtle changes in visual perceptual motor integration in their series were related to low cord haemoglobin levels rather than high serum bilirubin concentrations. Somewhat similar findings were shown by Odell $e t$ al. (1970), who in 32 jaundiced neonates recorded not only serum bilirubin levels but also the saturation index of the serum proteins with bilirubin. Though they found no correlation between serum bilirubin levels and I.Q. scores there was a highly significant one between the serum saturation index and abnormal cognitive findings on psychological testing at 4-7 years.

While there seems to be no statistical correlation between serum bilirubin levels per se (up to $20 \mathrm{mg}$. per $100 \mathrm{ml}$.) and subsequent I.Q., individual examples of frank kernicterus occurring at quite low levels of serum bilirubin have been described (Stern and Denton, 1965). Clearly serum bilirubin itself is not a precise measure of the risk of brain damage. Other factors such as anaemia (Stewart et al., 1970), hypoxia (Lucey et al., 1964), acidaemia (Windle, 1969), and hypoglycaemia operating in the first few days of life may affect the situation in at least three ways. (1) They may cause brain damage in their own right. (2) They may interfere with protein binding of bilirubin in the plasma and thus cause kernicterus at unexpectedly low bilirubin levels. (3) They may combine with bilirubin toxicity at cellular level to interfere with respiration, giving rise to complex neurological damage requiring subtle testing for detection and evaluation. There is thus need for a more complete evaluation of the neonate to be recorded together with new methods such as the protein saturation index (Odell et al., 1970) and the reserve albumin binding capacity (Porter and Waters, 1966) to be taken into account. This will need careful psychological assessment at around 5 years of age. Until these methods have been properly assessed the paediatrician must interpret the serum bilirubin level along with the other criteria, not forgetting the clinical state of the baby. Meanwhile, there is no evidence of a significant iceberg of lowered intelligence occurring at bilirubin levels below that at which kernicterus is to be expected, and current indications for exchange transfusion and other treatment remain valid.

We thank the Mental Health Research Fund for enabling the psychological testing to be carried out and Mr. C. J. Phillips for making the data available to us. Mr. N. L. Crabtree and Mr. G. A. Dalton kindly arranged the audiological testing. The parents of these children were very co-operative by attending for follow-up, which was greatly facilitated with the aid of Dr. D. F. Mahon, senior administrative medical officer for personal and child health, and his staff.

\section{REFERENCES}

Bjure, J., Lidén, G., Reinand, F., and Vestby, A. (1961). Acta Paediatrica Scandinavica, 50, 437.

Boggs, T. R., Hardy, J. B., and Frazier, T. M. (1967). fournal of Paediatrics, 71, 553.

Day, R., and Haines, M. S. (1954). Pediatrics, 13, 333

Drillien, C. M. (1964). The Growth and Development of the Prematurely Born Infant. Edinburgh, Livingstone.

Gerrard, J. (1952). Brain, 75, 526.

Griffiths, R. (1954). The Abilities of Babies. London, University of London Press.

Holmes, G. E., Miller, J. B., and Smith, E. E. (1968). American fournal of Diseases of Children, 116, 37.

Johnston, W. H., et al. (1967). Pediatrics, 39, 88.

Lucey, J. F., Hibbard, E., Behrman, R. E., Esquivel de Gallardo, F. O., and Windle, W. F. (1964). Experimental Neurology, 9, 43.

McDonald, A. (1967). Children of Very Low Birth Weight. London, Spastics Society and Heinemann Medical.

Mollison, P. L., and Cutbush, M. (1954) In Recent Advances in Paediatrics, ed. D. M. T. Gairdner, p. 110. London, Churchill.

Odell, G. B., Storey, G. N. B., and Rosenberg, L. A. (1970). Fournal of Pediatrics, 76, 12.

Ose, T., Tsuruhara, T., Araki, M., Hanaoka, T., and Bush, O. B. (1967). Pediatrics, 40, 196.

Porter, E. G., and Waters, W. J. (1966). Fournal of Laboratory and Clinical Medicine, 67, 660.

Preisler, O., Gronau, M., and Horstmann, W. (1963). Deutsche medizinische Wochenschrift, 88, 1828.

Stern, L., and Denton, R. L. (1965). Pediatrics, 35, 483.

Stewart, R. R., Walker, W., and Savage, R. D. (1970). Developmental Medicine and Child Neurology, 12, 16.

Van Camp, D. (1964). American fournal of Mental Deficiency, 68, 803.

Vuchovich, D. M., Haimowitz, N., Bowers, N. D., Cosbey, J., and Hsia, D. Y. Y. (1965). Fournal of Mental Deficiency Research, $\mathbf{9}, 51$.

Waltman, R., Bonura, F., Nigrin, G., and Pipat, C. (1969). Lancet, 2, 1265.

Windle, W. F (1969) Scientific American, 221,

Wood, B. S. B., Culley, P. E., Waterhouse, J. A. H., and Powell, D. J. (1962). Archives of Diseases in Childhood, 37, 371 .

\section{Preliminary Communications}

\section{Serum Creatine Phosphokinase Levels in Pigs Reacting Abnormally to Halogenated Anaesthetics}

British Medical fournal, 1970, 3, 386-387

Summary: Serum levels of creatine phosphokinase
(CPK) were estimated in pigs. Among those known
to react abnormally either to halothane alone or to halo-
thane and suxamethonium most had very high levels of
CPK. Twenty-four hours after five minutes' anaesthesia
with halothane and oxygen a sustained, pronounced rise
in the serum CPK occurred in some pigs-principally
but not exclusively in the abnormal reactors. Estimation
of the serum level of CPK may be a useful screening
test for an abnormal hyperpyrexial response to halothane.

\section{INTRODUCTION}

There are now many reports of an abnormal response, both in humans and in animals, to halogenated anaesthetic agents either alone or in combination with suxamethonium chloride (Denborough and Lovell, 1960; Britt and Gordon, 1969). This response is characterized by the development of generalized muscle rigidity, a severe and sustained rise in body temperature, hyperkalaemia, and metabolic acidosis. Many of the human cases have had a familial distribution, and death occurs in a high proportion of them.
Hall et al. (1966) in Britain and Harrison et al. (1969) in South Africa have discovered strains of pig which, when exposed to these anaesthetic agents, develop a syndrome clinically similar to that found in humans, and thus, by good fortune, seem to have identified an experimental model for the investigation of this baffling and potentially lethal sequence of events. Most of the affected animals identified by Hall and his colleagues have been very closely related, though a few sporadic cases in unrelated animals have been noted. The data obtained from breeding experiments suggest that the abnormal reaction pattern is inherited as an autosomal dominant of variable penetrance and variable expressivity.

Our clinical findings and those of Harrison et al. suggest that the primary abnormality is to be found within the voluntary muscle of the affected animals. We have therefore attempted to find a biochemical "marker" which could support this suggestion and which might serve to identify experimental animals or human patients who are at risk.

Raised serum creatine phosphokinase (CPK) levels have been reported in a number of myopathies both in humans and in experimental animals (Eppenberger et al., 1964; Wilson et al., 1965) and there are also reports of raised serum CPK levels in relatives of patients who have reacted abnormally to halothane and suxamethonium (Denborough et al., 1970; Isaacs and Barlow, 1970). We decided, therefore, to study the serum levels of this enzyme in our strain of abnormally reacting pigs. 